\title{
Кто и как преподавал языки в Петербургской академии наук в XVIII в.?
}

\section{How were Languages Taught and by Whom at The St. Petersburg Academy of Sciences in the Eighteenth Century?}

\author{
Татьяна Костина \\ Санкт-Петербургский институт истории Российской Академии наук \\ Tatiana Kostina \\ Saint-Petersburg Institute of History of the Russian Academy of Sciences \\ tatianav.kostina@gmail.com
}

Рецензия на книгу: Л. В. Московкин, Языковое образование в Академическом университете и гимназии в XVIII веке. Санкт-Петербург: Издательство СанктПетербургского университета, 2019. 144 c.

Review of: L. V. Moskovkin, Language Education at the Academic University and Gymnasium in the Eighteenth Century. St. Petersburg: Izdatel'stvo Sankt-Peterburgskogo Universiteta, 2019. 144 p.

История учебных заведений Петербургской Академии наук, не имеющая со времен брошюр Д. А. Толстого ${ }^{2}$ обзорной монографической работы, в которой они исследовались бы специально и на всем периоде своего существования, является сейчас динамично меняющимся исследовательским полем. Если до последнего десятилетия значимые работы выходили раз в несколько лет, ${ }^{3}$ то в настоящее время

\footnotetext{
1 Работа выполнена при финансовой поддержке РФФИ и ФДНЧ, в рамках научного проекта № 20-51322001.

2 Д. А. Толстой, Академический университет в XVIII столетии, по рукописным документам архива Академии наук (Санкт-Петербург: Академия наук, 1885). (D. A. Tolstoi, Akademicheskii universitet $v$ XVIII stoletii, po rukopisnym dokumentam arkhiva Akademii nauk (St. Petersburg: Akademiia nauk, 1885); Д. А. Толстой, Академическая гимназия в XVIII столетии, по рукописным документам архива Академии наук (Санкт-Петербург: Академия наук, 1885). (D. A. Tolstoi, Akademicheskaia gimnaziia v XVIII stoletii, po rukopisnym dokumentam arkhiva Akademii nauk (St. Petersburg: Akademiia nauk, 1885)).

${ }^{3}$ E. Amburger, "Die nichtrussischen Schüler des Akademischen Gymnasiums in St. Petersburg 1726-1750" in Beiträge zur Geschichte der deutsch-russischen kulturellen Beziehungen (Giessen: Wilhelm Schmitz, 1961), 183213; Е. С. Кулябко, М. В. Ломоносов и учебная деятельность Петербургской Академии наук (МоскваЛенинград: Издательство АН CСCP, 1962) (Е. S. Kuliabko, M. V. Lomonosov $i$ uchebnaia deiatel'nost' Peterburgskoi Akademii nauk (Moscow-Leningrad: Izdatel'stvo AN SSSR, 1962); Е. С. Кулябко, Замечательные питомиы Академического университета (Ленинград: Наука, 1977). (Е. S. Kuliabko, Zamechatel'nye pitomtsy Akademicheskogo universiteta (Leningrad: Nauka, 1977)); H. Keipert, "Die Petersburger 'Teutsche Grammatika' und die Anfänge der Russistik in Rußland" in Studia slavica in honorem viri doctissimi Olexa Horbatsch, 3. (Munich: O. Sagner, 1983), 77-140; H. Keipert, "Der Fremdsprachenunterricht in der Frühzeit des Petersburger Akademie-Gymnasiums," Polata Knigopisnaia: an Information Bulletin Devoted to the Study of Early Slavic Books, Texts and Literatures, 16, August (1987), 68-82; Ю. Д. Марголис, Г. А. Тишкин, Отечеству на пользу, а россиянам во славу: Из истории университетского образования в Петербурге в ХVIII- начале XIX в. (Ленинград: Издательство ЛГУ, 1988). (Iu. D. Margolis, G. A. Tishkin, Otechestvu na pol'zu, a rossiianam vo slavu: Iz istorii universitetskogo obrazovaniia v Peterburge v XVIII-nachale XIX v. (Leningrad: Izdatel'stvo LGU, 1988)); H. Keipert, "Vasilij Lebedev und sein Sokraščenie grammatiki latinskoj (S.-Peterburg 1746)" in Res slavica. Festschrift für Hans Rothe zum 65. Geburtstag (Paderborn, München, 1994), 117-133; Ю. Х. Копелевич, "Первые
} 
ежегодно выходит по несколько статей разных авторов, основанных на неопубликованных документах и нередко нацеленных на разработку смежных проблем. ${ }^{4}$ Изучение истории преподавания языков в этих учебных заведениях, исследование созданных для этого учебных пособий, - одни из центральных направлений исследовательского поиска.

Такое внимание не удивительно, ведь на XVIII в. пришлось становление методик преподавания как иностранных языков для носителей русского языка, так и русского языка для иностранцев, а также различных, малоизученных еще вариантов би- и полилингвального образования. Учебные пособия, созданные для учеников Академической гимназии, во многих случаях оказались базовыми для

академические студенты," Вопросы истории естествознания и техники, 1996, № 2, 4-15. (Iu. Kh. Kopelevich, "Pervye akademicheskie studenty," Voprosy istorii estestvoznaniia i tekhniki, 1996, № 2, 4-15); Г. И. Смагина, “Публичные лекции Санкт-Петербургкой Академии наук во второй половине XVIII в.," Bonpocbl истории естествознания и техники, 1996, № 2, 16-26. (G. I. Smagina, "Publichnye lektsii Sankt-Peterburgkoi Akademii nauk vo vtoroi polovine XVIII v.," Voprosy istorii estestvoznaniia i tekhniki, 1996, № 2, 16-26.); Ю. Д. Марголис, Г. А. Тишкин, “Единым вдохновением”. Очерки истории университетского образования в Петербурге в конце XVIII - первой половине XIX в. (Санкт-Петербург: Санкт-Петербургский университет, 2000). (Iu. D. Margolis, G. A. Tishkin, “Edinym vdokhnoveniem”. Ocherki istorii universitetskogo obrazovaniia v Peterburge v kontse XVIII - pervoi polovine XIX v. (St. Petersburg: Sankt-Peterburgskii universitet, 2000)); K. Koch, Deutsch als Fremdsprache im Russland des 18. Jahrhunderts (Berlin: Walter de Gruyter, 2002); Г. И. Смагина, “Академия наук и зарождение университетского образования в России” в Академия наук 6 истории культуры России XVIII-XX веков (Санкт-Петербург: Наука, 2010), 39-80. (G. I. Smagina, “Akademiia nauk i zarozhdenie universitetskogo obrazovaniia v Rossii” in Akademiia nauk $v$ istorii kul'tury Rossii XVIII-XX vekov (St. Peterburg: Nauka, 2010), 39-80.).

4 А. А. Костин, Т. В. Костина, "Регламент Гимназии при Императорской академии наук в СанктПетербурге» Георга Вольфганга Крафта 1739 года и его подготовка” в И. И Федюкин и М. Б. Ларинович, ред., “Регулярная академия учреждена будет”: Образовательные проекты в России в первой половине XVIII века (Москва: Новое издательство, 2015), 47-60. (А. A. Kostin, T. V. Kostina, “'Reglament Gimnazii pri Imperatorskoi akademii nauk v Sankt-Peterburge' Georga Vol'fganga Krafta 1739 goda i ego podgotovka” in I. I Fediukin and M. B. Larinovich, red., 'Regulianaia akademiia uchrezhdena budet': Obrazovatel'nye proekty $v$ Rossii v pervoi polovine XVIII veka (Moscow: Novoe izdatel'stvo, 2015), 47-60); Н. В. Карева, М. Л. Сергеев, “Первая печатная грамматика французского языка (1752): к вопросу о переводческих принципах В.Е. Теплова,” Вестник Санкт-Петербургского университета. Сер. 9, 2016, вып. 1, 58-69. (N. V. Kareva, M. L. Sergeev, "Pervaia pechatnaia grammatika frantsuzskogo iazyka (1752): k voprosu o perevodcheskikh printsipakh V. E. Teplova," Vestnik Sankt-Peterburgskogo universiteta. Ser. 9, 2016, vур. 1, 58-69); О. А. Кирикова, Т. В. Костина, “Учебные книги в гимназии Академии наук 1730-х гг.," Детские чтения, 2018, № 1, 194-219 (O. A. Kirikova, T. V. Kostina, “Uchebnye knigi v gimnazii Akademii nauk 1730-kh gg.,” Detskie chteniia, 2018, № 1, 194-219); T. В. Костина, “Подготовка элит Российской Империи в учебных заведениях Академии наук (1726-1805)” в И. В. Тункина, ред. Актуальное прошлое: взаимодействие и баланс интересов Академии наук и российского государства в XVIII - начале XX в. Очерки истории. Кн. I (Санкт-Петербург: Реноме, 2018), 207-302. (T. V. Kostina, "Podgotovka elit Rossiiskoi Imperii v uchebnykh zavedeniiakh Akademii nauk (1726-1805)" in I. V. Tunkina, red. Aktual'noe proshloe: vzaimodeistvie i balans interesov Akademii nauk $i$ rossiiskogo gosudarstva $v$ XVIII - nachale XX v. Ocherki istorii. Kn. I (St. Petersburg: Renome, 2018), 207-302); М. Л. Сергеев, "К вопросу о значении немецких учебных пособий для преподавания французского языка в России в XVIII в.," Journal of applied linguistics and lexicography, 2019, vol. 1, № 1, 102-116 (M. L. Sergeev, "K voprosu o znachenii nemetskikh uchebnykh posobii dlia prepodavaniia frantsuzskogo iazyka v Rossii v XVIII v.," Journal of applied linguistics and lexicography, 2019, vol. 1, № 1, 102-116); Н. В. Карева, Е. Г. Пивоваров, “Первая в России грамматика немецкого языка: история создания и источники,” Вестник Волгоградского государственного университета. Сер. 2: Языкознание, 2019, т. 18, № 4, 18-28 (N. V. Kareva, E. G. Pivovarov, "Pervaia v Rossii grammatika nemetskogo iazyka: istoriia sozdaniia i istochniki", Vestnik Volgogradskogo gosudarstvennogo universiteta. Ser. 2: Iazykoznanie, 2019, t. 18, № 4, 18-28); Т. В. Костина, “О Академии ученья языкам»: преподавание и изучение языков в Академической гимназии 1726-1727 гг.” в Труды Государственного Эрмитажа. [T.] 101: Петровское время в лицах - 2019: материаль научной конференции (СанктПетербург: Издательство Гос. Эрмитажа, 2019), 191-197. (T. V. Kostina, “O Akademii uchen'ia iazykam»: prepodavanie i izuchenie iazykov v Akademicheskoi gimnazii 1726-1727 gg." in Trudy Gosudarstvennogo Ermitazha. [T.] 101: Petrovskoe vremia v litsakh - 2019: materialy nauchnoi konferentsii (St. Petersburg: Izdatel'stvo Gos. Ermitazha, 2019), 191-197). 
преподавания языков в Российской империи, по меньшей мере, на полвека и стали моделями для дальнейшей традиции создания учебной литературы в России. До перехода учебного процесса на русский язык без усвоения иностранных языков (немецкого для Академической гимназии, латинского для Университета) нельзя было получить образования за пределами элементарного чтения и письма на русском и церковнославянском языках. Но и после перехода на русский язык обучения невозможно было стать образованным человеком, не читая книг на иностранных языках. Владение языками делало человека конкурентоспособным в областях, требующих передающегося словом экспертного знания, потому что переводная литература не могла еще удовлетворить экспертных запросов на знание, соответствующее развитию научной мысли. При большом внимании, которое уделялось в процессе обучения чтению авторов, прежде всего древних, образование, особенно в первой трети XVIII в., и заключалось по сути в освоении поведенческих моделей, риторических приемов и теоретической мысли, изложенных на латинском и других иностранных языках. Без понимания истории освоения иностранных языков в России XVIII века невозможно понять ее историю этого времени. На этом фоне выход монографии по означенной теме, обобщающей архивные разыскания автора, не может не привлечь внимания специалистов, тем более, что Л. В. Московкин хорошо известен своими полезными статьями по истории грамматик для преподавания русского языка как иностранного в XVIII в. ${ }^{5}$

В монографии Л. В. Московкин сосредоточил свое внимание на трех аспектах описанной проблематики. Во-первых, его интересовало определение сроков преподавания языков и на иностранных языках. Во-вторых, рассмотрение истории изучения всех языков, которые появлялись в учебном процессе за 8о лет существования при Петербургской Академии наук учебных заведений. И, в-третьих, реконструкция биографий лиц, связанных с преподаванием языков в Академии наук. Осветить эти вопросы удалось в разной степени. Например, в третьей главе, которая представляет собой биографический словарь, можно найти биографии всех преподавателей языков, что, несомненно, сделает востребованной рецензируемую книгу. С другой стороны, история преподавания языков в монографии зачастую сводится к описанию учебной литературы, созданной и использовавшейся в учебных заведениях Академии. А ведь это не столько история учебников, сколько история методов преподавания, чему в книге уделено недостаточно внимания. Если, ознакомившись с книгой, мы можем составить почти исчерпывающее представление о том, кто преподавал языки, то ученики и студенты Академии появляются в книге лишь эпизодически (при описании преподавания латинского, французского и русского языков). А ведь многонациональный, преимущественно

\footnotetext{
5 С. В. Власов, Л. В. Московкин, “Из истории создания учебников русского языка как иностранного в России: ‘Основы русского языка' Шарпантье и Мариньяна (1768),” Мир русского слова, 2007, № 1-2, 72-80 (C. V. Vlasov, L. V. Moskovkin, "Iz istorii sozdaniia uchebnikov russkogo iazyka kak inostrannogo v Rossii: 'Osnovy russkogo iazyka' Sharpant'e i Marin'iana (1768),” Mir russkogo slova, 2007, № 1-2, 72-80); С. В. Власов, Л. В. Московкин, “Из истории создания учебников русского языка как иностранного в России: грамматика французская и русская (1730 год),” Мир русского слова, 2008, № 2, 82-90 (C. V. Vlasov, L. V. Moskovkin, “Iz istorii sozdaniia uchebnikov russkogo iazyka kak inostrannogo v Rossii: grammatika frantsuzskaia i russkaia (1730 god)," Mir russkogo slova, 2008, № 2, 82-90); В. Власов, Л. В. Московкин, “Некоторые новые соображения по поводу истории создания 'Грамматики французской и русской' 1730 года,” Вестник Санкт-Петербургского университета. Сер. 9: Филология. Востоковедение. Журналистика, 2013, № 3, 125-137. (V. Vlasov, L. V. Moskovkin, "Nekotorye novye soobrazheniia po povodu istorii sozdaniia 'Grammatiki frantsuzskoi i russkoi' 1730 goda,” Vestnik Sankt-Peterburgskogo universiteta. Ser. 9: Filologiia. Vostokovedenie. Zhurnalistika, 2013, № 3, 125-137) и др.
} 
билингвальный (русско-немецкий) состав учеников не мог не влиять и на систему, и на методику преподавания языков, прежде всего, немецкого.

Структура опубликованной монографии вполне логична. Помимо предисловия, заключения, списков сокращений и иллюстраций в ней три главы. Первая названа “Императорская Академия наук и ее учебные подразделения;" вторая “Преподаваемые языки и учебники” а третья, самая объемная, - “Персоналии.”

Предисловие уточняет, что в первой главе “кратко описана история Императорской Академии наук, Академического университета и Академической гимназии в XVIII в., но главное, на чем акцентируется внимание читателя, - это то, на каких языках осуществлялось преподавание учебных предметов в подразделениях Академии наук.” В первом параграфе кратко, на 4,5 страницах, пересказывается история Академии наук. Автор изложил в ней, казалось бы, уже известные в научной литературе факты. Однако излишне конспективный стиль изложения способствовал появлению некоторых неточностей. Они встречаются и в работах других коллег, поэтому заслуживают отдельного разговора.

Л. В. Московкин пишет: “Первым русским научным сотрудником Академии стал в 1733 г. В. Е. Адодуров, занявший должность адъюнкта по кафедре высшей математики.” Хотя этот тезис, в целом, принят сейчас в научной литературе, он не соответствует действительности. Во-первых, термин “научный сотрудник" анахроничен. Во-вторых, первыми русскими “научными сотрудниками” правильнее, как кажется, считать первых русских студентов: Василия Яворского и Филиппа Львовича Анахина. ${ }^{7}$ Последний в 1726-1728 гг. занимался математикой под руководством профессора $\Phi$. Х. Майера, переехал с ним в Москву в качестве переводчика. ${ }^{8}$ Но, главное, Адодуров был адъюнктом и до 1733 г. Вероятнее всего, он был повышен в звании за сочинение Anfangs-Gründe der Rußischen Sprache, изданное в 1731 г. К сожалению, пока не удается найти в архиве точного указания на его производство, однако находятся неоднократные упоминания адъюнкта Адодурова в источниках до 1733 г., в т.ч. опубликованных. 9 Как адъюнкт с 1731 г. он указан в именном указателе к изданию “Летопись жизни и творчества М. В. Ломоносова.” Второе замечание относится к перечислению членов Российского собрания, среди которых исследователями оказался незаслуженно забыт советник Камер-коллегии Ф. И. Эмме. Как выяснилось, он не только принимал активное участие в заседаниях, но и перевел на русский язык Kurtze Einleitung zur mathematischen und natürlichen

\footnotetext{
6 Л. В. Московкин, Языковое образование в Академическом университете и гимназии в XVIII веке (СанктПетербург: Издательство Санкт-Петербургского университета, 2019), 6. (L. V. Moskovkin, Iazykovoe obrazovanie $v$ Akademicheskom universitete $i$ gimnazii $v$ XVIII veke (St. Petersburg: Izdatel'stvo SanktPeterburgoskogo universiteta, 2019), 6).

${ }^{7}$ Материалы для истории Императорской Академии наук (далее: МАН), т. 1. (1716-1730) (Санкт-Петербург: Типография императорской академии наук, 1885), 286. (Materialy dlia istorii Imperatorskoi Akademii nauk (dalee: MAN), t. 1. (1716-1730) (St. Petersburg: Tipografiia imperatorskoi akademii nauk, 1885), 286).

${ }^{8}$ Санкт-Петербургский филиал Архива РАН (далее СПбФ АРАН), ф. 3, оп. 1, д. 2, л. 25 об., 28 об., 33 ; д. 4, л. 31-35; д. 791, л. 18-25 (Sankt-Peterburgskii filial Arkhiva RAN (dalee SPbF ARAN), f. 3, op. 1, d. 2 , 1.25 ob., 28 ob., 33; d. 4, 1. 31-35; d. 791, 1. 18-25).

9 MAН, т. 2. (1731-1735) (Санкт-Петербург, 1886), 122 (MAN, t. 2. (1731-1735) (St. Petersburg, 1885), 286); Санкт-Петербургский филиал Архива РАН (далее СПбФ АРАН), ф. 3, оп. 1, д. 787, л. 22 об.; д. 791, л. 89 (Sankt-Peterburgskii filial Arkhiva RAN (dalee SPbF ARAN), f. 3, op. 1, d. 787, 1. 22 ob.; d. 791, 1. 89).

${ }^{10}$ А. В. Топчиев, Н. А. Фигуровский, В. Л. Ченакал, ред. Летопись жизни и творчества М. В. Ломоносова (Москва-Ленинград: Издательство АН СССР, 1961), 419. (А. V. Topchiev, N. A. Figurovskii, V. L. Chenakal, red. Letopis' zhizni i tvorchestva M. V. Lomonosova (Moscow-Leningrad: Izdatel'stvo AN SSSR, 1961), 419).
} 
Geographie Г. В. Крафта (1738). Это учебник, опубликованный в 1739 г. под названием “Краткое руководство к математической и натуральной географии.”"1

Искажения допущены и в следующих двух параграфах, посвященных истории Университета и Гимназии. На с. 17 сказано, что "Регламент Академии наук" был подтвержден Екатериной I в 1727 г., тогда как известно, что документ остался без утверждения, хотя и использовался на практике в Академии. ${ }^{12}$ Составленный 20 сентября 1725 г. на немецком языке и переведенный 27 сентября на русский язык "Регламент" был ошибочно датирован при публикации в "Материалах для истории Императорской Академии наук” 1727 г. $^{13}$ Вероятно, именно это стало причиной неверной датировки, повторенной в книге. Не выглядит обоснованным утверждение на с. 21 о том, что Гимназию и Университет объединил Л. И. Бакмейстер, и что они при этом сохраняли свою сложившуюся структуру. На большую роль Бакмейстера в реформировании курса гимназического преподавания указали Ю. Д. Марголис и Г. А. Тишкин в монографии "Единым вдохновением.' Очерки истории университетского образования в Петербурге в конце XVIII первой половине XIX в.," но позднее выяснилось, что организатором преобразования учебных заведений был директор Академии В. Г. Орлов. ${ }^{14}$ Не могу также не напомнить об уже установленном факте, что кроме М. В. Ломоносова и С. П. Крашенинникова лекции на русском языке по политической географии читал в 1748-1749 гг. студент Василий Гаврилович Кузнецов. ${ }^{15}$ На с. 21 Л. В. Московкин пишет: “Число учеников гимназии не было постоянным: в 1726 г. - 112, в 1759 г. - 40, в 1779 г. - 29, в 1802 г. - 87, в 1805 г. - 55.” Это утверждение вводит в заблуждение, потому что речь в нем идет о числе поступивших учеников в означенные годы, а не об общей численности учащихся. В 1759 г. продолжали учиться 30 учеников поступивших в 1758 г., не менее 29 поступивших в 1757 г., да и из поступивших в 1756 г. выбыли только отдельные учащиеся. Аналогичным образом можно рассказать обо всех упомянутых годах, кроме 1726-го, поскольку в первый год существования учебного заведения число поступивших, конечно, совпадало с общей численностью учеников. В 1805 г., при расформировании Гимназии, число ее учеников не было равно 55 ученикам, которые были переведены в пансион Санкт-Петербургской

${ }^{11}$ МАН, т. 2. (1731-1735) (Санкт-Петербург, 1886), 696, 828 (MAN, t. 2. (1731-1735) (St. Petersburg, 1886), 696, 828); А. А. Костин, Т. В. Костина, “Русский автор’ в 1739 году: Т. З. Байер, И. И. Тауберт и формирование русского школьного канона," Slověne= Словъне: International Journal of Slavic Studies, 2019, vol. 8, № 2, 189 (A. A. Kostin, T. V. Kostina, “'Russkii avtor’ v 1739 godu: T. Z. Baier, I. I. Taubert i formirovanie russkogo shkol'nogo kanona,” Slověne= Slovrone: International Journal of Slavic Studies, 2019, vol. 8, № 2, 189).

12 Ю. Х. Копелевич, Основание Петербургской Академии наук (Ленинград: Наука, 1977), 83-84. (Iu. Kh. Kopelevich, Osnovanie Peterburgskoi Akademii nauk (Leningrad: Nauka, 1977), 83-84).

${ }^{13}$ СПбФ АРАН, ф. 3, оп. 1, д. 785, л. 169-170 (SPbF ARAN, f. 3, op. 1, d. 785, 1. 169-170); MAH, т. 1. (17161730) (Санкт-Петербург, 1885), 297-324 (MAN, t. 1. (1716-1730) (St. Petersburg, 1885), 297-324).

14 Т. В. Костина, “Когда и куда 'пропал' Академический университет: реформа учебных заведений Академии наук 1765-1770 гг.” в А. Ю. Дворниченко, ред., Мавродинские чтения 2018: Maтериаль Всероссийской научной конференции, посвященной 110-летию со дня рождения профессора Владимира Васильевича Мавродина (Санкт-Петербург: Нестор-история, 2018), 510-513. (Т. V. Kostina, "Kogda i kuda 'propal' Akademicheskii universitet: reforma uchebnykh zavedenii Akademii nauk 1765-1770 gg." in A. Iu. Dvornichenko, red., Mavrodinskie chteniia 2018: Materialy Vserossiiskoi nauchnoi konferentsii, posviashchennoi 110-letiiu so dnia rozhdeniia professora Vladimira Vasil'evicha Mavrodina (St. Petersburg: Nestor-istoriia, 2018), 510-513).

15 Т. В. Костина, "Подготовка элит Российской Империи в учебных заведениях Академии наук (1726-1805)" в И. В. Тункина, ред. Актуальное прошлое: взаимодействие и баланс интересов Академии наук и российского государства в XVIII - начале XX в. Очерки истории. Кн. I (Санкт-Петербург: Реноме, 2018$), 259$. (T. V. Kostina, "Podgotovka elit Rossiiskoi Imperii v uchebnykh zavedeniiakh Akademii nauk (1726-1805)" in I. V. Tunkina, red. Aktual'noe proshloe: vzaimodeistvie i balans interesov Akademii nauk i rossiiskogo gosudarstva $v$ XVIII - nachale XX v. Ocherki istorii. Kn. I (St. Petersburg: Renome, 2018), 259). 
губернской гимназии, потому что еще не менее 18 учеников были приняты на Академическую службу или возвращены родителям. Большое, значимое для Петербурга учреждение из-за неверно поданной статистики искусственно уменьшается в восприятии читателя раз в пять-шесть, если учесть, что часть учащихся находилась в Гимназии по 5-12 лет.

Вторая часть монографии посвящена краткому описанию истории преподавания в учебных заведениях Академии наук языков: немецкого, латинского, французского, древнегреческого, русского, итальянского, английского, японского и китайского.

При описании преподавания немецкого языка Л. В. Московкин обрисовывает истоки преподавания этого языка в России; представляет общий план преподавания, принятый в Академической гимназии. Центральный вопрос этого подраздела - формирование комплекса учебных пособий для преподавания немецкого языка. Достаточно подробно описывается появление изданий основных пособий: “Немецкой грамматики” М. Шванвица, “Вейсманова лексикона," “Домашних разговоров.” При этом совсем не упоминается и не принимается во внимание билингвальный состав учеников Гимназии.

Рассказывая о преподавании латинского языка, Л. В. Московкин использует понятие «научная латынь», поясняя, что это “функциональная разновидность этого языка, знание которой было необходимо тем, кто занимается наукой, преподает

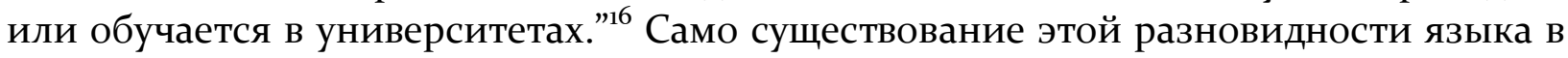
России XVIII в. вызывает сомнение. Приведенный Московкиным аргумент доучивание латыни “выпускниками духовных семинарии” при поступлении их в университет в старших классах Академической гимназии, в действительности, не состоятелен. Доучиваться в Гимназию, действительно, отправляли, но не “выпускников," а тех, кто был набран в разных классах семинарий и духовных академий: от синтаксиса (М. Коврин, Н. Попов) до философии (В. Лебедев). Вместе с тем до сих пор специалисты, кажется, не указывали на большую разницу между латинским языком, употреблявшимся при Петербургской академии наук и латинским языком, которому учили в духовных учебных заведений. ${ }^{17}$ Если она была, то это должно быть предметом специального исследования. Работа, проделанная Е. И. Кисловой в отношении преподавания латинского языка в семинариях, показала, что отличия можно искать в методике преподавания и употреблении отдельных пособий (например, в широком использовании “Грамматики” Э. Альвара при семинариях, чего не наблюдалось в Академической гимназии), но не в общем

\footnotetext{
16 Л. В. Московкин, Языковое образование в Академическом университете и гимназии в XVIII веке (СанктПетербург: Издательство Санкт-Петербугрского университета, 2019), 31ю (L. V. Moskovkin, Iazykovoe obrazovanie $v$ Akademicheskom universitete $i$ gimnazii $v$ XVIII veke (St. Petersburg: Izdatel'stvo SanktPeterburgskogo. universiteta, 2019), 31).

17 Я. М. Боровский, “Латинский язык как международный язык науки” в М. И. Исаев, ред., Проблемы международного вспомогательного языка. (Москва: Наука, 1991), 70-76 (Ia. M. Borovskii, "Latinskii iazyk kak mezhdunarodnyi iazyk nauki” in M. I. Isaev, red., Problemy mezhdunarodnogo vspomogatel'nogo iazyka. (Moscow: Nauka, 1991), 70-76); Д. Л. Либуркин, Русская новолатинская поэзия: материаль к истории. XVII - первая половина XVIII века (Москва: Российский государственный гуманитарный университет, 2000). (D. L. Liburkin, Russkaia novolatinskaia poeziia: materialy $k$ istorii. XVII - pervaia polovina XVIII veka (Moscow: Rossiiskii gosudarstvennyi gumanitarnyi universitet, 2000)); В. С. Ржеуцкий, “Латинский язык в дворянском образовании в России XVIII века" в А. А. Костин, ред., Чтения отдела русской литературы XVIII века, вып. 8 (Москва; Санкт-Петербург: Альянс-Архео, 2018), 228-250. (V. S. Rzheutskii, "Latinskii iazyk v dvorianskom obrazovanii v Rossii XVIII veka" in A. A. Kostin, red., Chteniia otdela russkoi literatury XVIII veka, vyp. 8 (Moscow-St. Petersburg: Al'ians-Arkheo, 2018), 228-250).
} 
направлении преподавания и его ориентации на изучение разных текстов: светских в Гимназии и духовных в семинариях. ${ }^{18}$

Также без ссылок на документы в книге Л. В. Московкина сказано, что при Академии наук использовали Orbis sensualium pictus Я. А. Коменского. Книга, предназначенная для начального обучения латыни, действительно, фигурирует в одной из составленных М. В. Ломоносовым черновых версий "списков книг, необходимых для обучения учеников Гимназии Академии наук.” Однако ее попадание в список пособий, рекомендованных для среднего латинского класса, вызывает вопросы у специалистов, а реальные заказы книги для гимназистов пока не выявлены, хотя на этот вопрос обращается особое внимание. ${ }^{19}$ В целом, как и в предыдущем подразделе, Л. В. Московкин описывает историю создания и употребления в Академической гимназии различных учебных пособий для преподавания латинского языка, и в этом качестве обзор может быть полезен исследователям.

Аналогичный, и довольно подробный, обзор грамматических учебников французского языка составляет основное содержание подраздела “Французский язык." Он резюмирует многолетние исследования этих грамматик, проведенные в России, в процессе которых были выявлены как обстоятельства создания, так и положенные в основу этих учебников источники.

Следующий параграф обобщает известные сведения о преподавании греческого языка. Представленный в нем материал вполне соответствует современному уровню развития знаний, а его изложение может считаться если не исчерпывающим, то вполне заслуживающим доверия. Интересно, что Московкин определяет 1732 г. как дату начала преподавания греческого языка и связывает его с деятельностью И. Э. Фишера, объясняя его отъездом и перерыв в преподавании греческого языка с 1739 до 1747 гг.

В подразделе "Русский язык” подробно рассматриваются попытки создания при Академии наук грамматик русского языка. Справедливо указывается на тот факт, что "Грамматика французская и русская" (1730) была адресована не ученикам Академической гимназии, а иностранным купцам, владеющим французским языком. Ранее автором монографии в соавторстве с С. В. Власовым были опубликованы специальные исследования, посвященные этому вопросу. ${ }^{20} \mathrm{~B}$ разделе хорошо прописаны периоды преподавания русского языка не только в Гимназии, но и в Университете. Однако описание преподавания русского языка после 1765 г. уводит от темы в разговор о заложенных М. В. Ломоносовым традициях

\footnotetext{
${ }^{18}$ Е. И. Кислова, “Учебные пособия по латыни и их использование в русских семинариях XVIII в.," Ученые записки Новгородского государственного университета, 2020, № 5 (30), 9 (E. I. Kislova, "Uchebnye posobiia po latyni i ikh ispol'zovanie v russkikh seminariiakh XVIII v.," Uchenye zapiski Novgorodskogo gosudarstvennogo universiteta, 2020, № 5 (30), 9).

${ }^{19}$ В. Г. Безрогов, "Die un/sichtbare Welt: рецепция Orbis sensualium pictus Я. А. Коменского в России 1-й пол. XVIII в.: образовательные практики и ранние переводы,” Детские чтения, т. 13, № 1 (2018), 240, 243 (V. G. Bezrogov, "Die un/sichtbare Welt: retseptsiia Orbis sensualium pictus Ia. A. Komenskogo v Rossii 1-i pol. XVIII v.: obrazovatel'nye praktiki i rannie perevody," Detskie chteniia, t. 13, № 1 (2018), 240, 243).

${ }^{20}$ С. В. Власов, Л. В. Московкин, "Из истории создания учебников русского языка как иностранного в России: грамматика французская и русская” (1730 год), "Мир русского слова, 2008, № 2, 82-90 (C. V. Vlasov, L. V. Moskovkin, "Iz istorii sozdaniia uchebnikov russkogo iazyka kak inostrannogo v Rossii: grammatika frantsuzskaia i russkaia” (1730 god)," Mir russkogo slova, 2008, № 2, 82-90); В. Власов, Л. В. Московкин, "Некоторые новые соображения по поводу истории создания «Грамматики французской и русской» 1730 года,” Вестник Санкт-Петербургского университета. Сер. 9: Филология. Востоковедение. Журналистика, 2013, № 3, 125-137. (V. Vlasov, L. V. Moskovkin, "Nekotorye novye soobrazheniia po povodu istorii sozdaniia 'Grammatiki frantsuzskoi i russkoi' 1730 goda", Vestnik Sankt-Peterburgskogo universiteta. Ser. 9: Filologiia. Vostokovedenie. Zhurnalistika, 2013, № 3, 125-137).
} 
преподавания русского языка, распространенных на другие школы Российской империи.

Подразделы о преподавании итальянского и английского языков не очень информативны, а их содержание заполнено преимущественно списками книг, про которые автором не установлено, использовали их в Академии наук или нет. Они вводятся почти одинаковыми словами “в процессе обучения могли использоваться следующие книги.” Особенно удивляет то, что в этих списках представлены исключительно книги, изданные в России на русском языке. В результате, в них не упомянут учебник, который, в действительности, использовался для преподавания английского языка, а именно - книга Даниэла Феннинга The Universal Spelling Book or, A new and easy guide to the English language, впервые изданная в 1756 г. Это учебное пособие в количестве 10 экземпляров заказывали для гимназистов в 1795 г.. ${ }^{21}$

Преподаванию японского и китайского языков в монографии уделены всего две страницы. В них конспективно показано время существования учебного процесса и, что немаловажно, указаны методы преподавания. На с. 25 сказано, что им обучали в Академическом университете. Это не соответствует действительности. Хотя среди профессоров университета и был Т. 3. Байер, изучавший и использовавший в научных целях китайский язык, студентам он преподавал латинский и греческий языки, науки об античных древностях. ${ }^{22}$ Школы японского и китайского языков существовали при Академии наук обособленно и отношение к учебным заведениям Академии наук имели опосредованное. Студенты восточные языки не изучали. Одного из студентов, Я. Несмеянова, планировали в 1739 г. отправить в составе посольства в Китай для ведения журналов и конторских книг ${ }^{23}$. Но даже его не пытались учить китайскому языку. Почти все ученики восточных языков посещали классы Академической гимназии, где учили европейские языки. Это позволяло им уйти на службу в учреждения, где восточные языки не требовались.

Весь обзор преподавания языков уместился у автора на 30 страницах вместе с обширным и не бесполезным списком литературы в конце, что кажется совершенно недостаточным для монографии, где вторая, центральная глава охватывает историю преподавания в Петербургской Академии наук девяти очень разных языков: древних и новых, русского и иностранных, европейских и восточных. Как и в случае с первой главой это способствовало конспективному стилю изложения, но, главное, автор неравномерно уделил внимание разным аспектам проблемы: если учебная литература, так или иначе, описана для всех языков, то система преподавания только для немецкого, латинского и, отчасти, русского и японского языков, а методика преподавания, по сути, только для китайского языка.

Последняя глава "Персоналии" занимает две трети объема книги и представляет собой словарь, в котором даны краткие сведения “об учителях и преподавателях русского и иностранных языков и о руководителях университета и гимназии; о выдающихся выпускниках университета и гимназии, ставших в дальнейшем преподавателями русского и иностранных языков в других учебных заведениях России, авторами известных учебников и словарей.” По глубине работы с материалом в этой части книги, по сравнению с двумя другими, можно предположить, что во многом ради нее и было выполнено данное издание.

\footnotetext{
${ }^{21}$ СПбФ АРАН, ф. 3, оп. 9, д. 519, л. 43 (SPbF ARAN, f. 3, op. 9, d. 519, 1. 43).

${ }^{22}$ МАН, т. 2. (1731-1735) (Санкт-Петербург, 1886), 223 (MAN, t. 2. (1731-1735) (St. Petersburg, 1886), 223).

${ }^{23}$ МАН, т. 4. (1739-1741) (Санкт-Петербург, 1887), 244 (MAN, t. 4 (1739-1741) (St. Peterbsurg, 1887 ), 244.
} 
Представляется спорным желание автора представить в словаре всех, кто имел отношение к преподаванию языков в России XVIII в.; включить в него не только преподавателей, но и “выдающихся выпускников университета и гимназии, ставших в дальнейшем преподавателями русского и иностранных языков в других учебных заведениях России, авторами известных учебников и словарей.” В этой конструкции большие вопросы вызывают сразу два определения: “выдающиеся” и "выпускники." Но и с учетом этого, очевидно, что при отборе персоналий отсутствовали строгие критерии. Ошибочно включен переводчик С. С. Волчков, который в учебных заведениях Академии наук и не учился, и не работал. Почему-то есть биография директора Академии наук Е. Р. Дашковой на том основании, что она реформировала преподавание языков, а о деятельности президента И. А. Корфа, настаивавшего на билингвальном, русско-немецком, обучении в Академической гимназии, в книге не упоминается.

Этот словарь можно и нужно дополнять и в отношении некоторых фактов поправлять. Например, Венедиктов Василий имеет отчество не Венедиктович, а Сидорович, родился 23 января 1744 г. в семье священника Сидора Венедиктова. ${ }^{24}$ Некоторым студентам в нем приписаны лишние годы учебы: И. И. Голубцов записан студентом с 1735 по 1740 гг., тогда как он только в 1736 г. стал гимназистом, а в студенты был переименован в 1738 г., ${ }^{25}$ А. П. Горланов поступил в университет в 1732, а не в 1730-м г. ${ }^{26}$ В книге констатируется инспекторство над Гимназией Л. Эйлера в 1737-1738 гг., тогда как до сих пор в научной литературе этому не представлено обоснования. Эйлер, действительно, в 1737 г., наряду с Г. З. Байером, Х. Гольдбахом и Г. В. Крафтом входил в Комиссию для выработки Регламента “о содержании учеников и об учении," ${ }^{27}$ но, представляется, что инспектором Гимназии оставался Байер до своей смерти 10 февраля 1738 г. Но все это не умаляет того факта, что с выходом книги Л. В. Московкина у исследователей появился словарь, где систематически учтены все преподаватели языков Академической гимназии. Книга сообщает в третьей главе множество новых фактов о значительном числе учителей Академической гимназии, после биографий которых приведены списки использованных источников и литературы. Это результат многолетней работы автора с источниками, в т.ч. архивными, в Российском государственном историческом архиве и, особенно много, в Санкт-Петербургском филиале Архива РАН.

K сожалению, в настоящее время доминирует формальный подход к определению ценности научных достижений. Монографии в иерархии таких ценностей стоят выше даже очень хороших словарей, тогда как по востребованности и полезности словари оставляют позади многие монографические исследования. Видимо, это стало главным мотивом при выборе формата представления собранного автором материала - материала важного и способного давать ответы на разные исследовательские вопросы. Рецензируемая книга объясняет, «на каком языке велось преподавание учебных предметов» и какие языки «преподавались в качестве отдельных учебных предметов». В некоторых случаях в ней приводится анализ методик преподавания. В ней

${ }^{24}$ СПбФ АРАН, ф. 3, оп. 1, д. 826, л. 253 об.; д. 827, л. 18, 60, 135 (SPbF ARAN, f. 3, op. 1, d. 826, 1. 253 ob.; d. $827,1.18,60,135)$.

${ }^{25}$ СПбФ АРАН, p. I, оп. 70, д. 20, д. 38 об. (SPbF ARAN, r. I, op. 70, d. 20, d. 38 ob.).

${ }^{26}$ MAН, т. 2. (1731-1735) (Санкт-Петербург, 1886), 96 (MAN, t. 2. (1731-1735). (St. Petersburg, 1885), 96).

${ }^{27}$ Протоколь заседаний Конференции Академии наук с 1725 по 1803 г., т. 1 (Санкт-Петербург, 1897), 417. (Protokoly zasedanii Konferentsii Akademii nauk s 1725 po 1803 g., t. 1 (St. Peterburg, 1897), 417). 
подробно описаны языковые учебники, созданные при Академии наук. При этом чаще внимание уделено источникам перевода этих учебников, чем причин, по которым одно пособие сменяло другое.

Книга, по-видимому, фиксирует как уровень достижений, так и проблемы, которые существуют на момент ее выхода в развитии дисциплины: сложности работы с многоязыковым делопроизводством учебных заведений Академии наук; с документами, сохранившимися в большом количестве, но рассеянными по разным фондам Санкт-Петербургского филиала Архива РАН и РГАДА. Это приводит к тому, что одному исследователю объять весь этот комплекс источников оказывается не под силу. Это же становится главным препятствием к появлению монографических работ об учебных заведениях Академии наук, обобщающих их историю на всем протяжении существования с 1724 по 1805 гг. Некоторые искажения, допущенные в первых главах рецензируемой книги, показывают назревшую необходимость в появлении работ по истории этих учебных заведениях, в которых были бы показаны перипетии реформирования учебного процесса в них в целом. Так что, в конечном счете, Л. В. Московкина можно только поблагодарить за то, что результаты его труда по систематизации сведений об учителях иностранных языков и разработанных ими учебных пособиях стали доступны другим исследователям. Книга вносит свой вклад в тему истории языкового образования в учебных заведениях Академии наук в XVIII в., однако, конечно же, не исчерпывает ее. 